\title{
From Mouth to Ear to Hand: Literacy as Recorded Orality in Nineteenth-and Early Twentieth-Century German Courts
}

\begin{abstract}
This research is situated in the legal context of contentious jurisdiction in Germany during the nineteenth and early twentieth centuries. By exploring the transcription of court proceedings (Gerichtsprotokolle), the article addresses the relationship between orality and literacy. Research on the production and use of court records shows that these two modes of communication were co-constitutive; the written word had to be retranslated into the spoken word in order to effect the agency of written artefacts as legal documents. The article reflects on the performativity of writing and the legal status of shorthand as part of rationalisation and modernisation of legal procedure, and deals with the obstacles which orality posed to literacy in the simultaneous acts of speaking, listening, and writing.
\end{abstract}

The relationship between orality and literacy is still crucial for the study of manuscript cultures. Researchers have tended to assume a fundamental change to this relationship that resulted in a shift of authority from the spoken to the written word. ${ }^{1}$ Yet the voices favouring a concept of reciprocity are increasing. ${ }^{2}$ In historical research on legal systems, the thesis that writing was the key element of social and cultural development seems to remain unchallenged. According to Jack Goody, writing was a prerequisite for both the codification of law and the record keeping of jurisprudence. Hence, he argues, 'written evidence in courts is characteristically given greater truth-value than oral testimony. This was so from the beginning. ${ }^{3}$ According to Goody, a fundamental shift took place from the mouth to the hand, and beyond that from the ear to the eye. In his view, 'reading permits a greater distancing between individual, language and reference than speech, a greater objectification which increases the analytic potential of the human mind'. ${ }^{4}$

\footnotetext{
1 Ong 1987; Benne 2015, 27, 581; Vismann 2011, 98-111.

2 Benne 2015; Gardey 2019, 36-37.

3 Goody 1986, 152.

4 Goody 1986, 142.
} 
It is uncontroversial that literacy is an essential component of bureaucratic technique in governance and regimes of power. A problem arises, however, when Goody primarily addresses the genre of Gerichtsprotokoll ('transcription of court proceedings') under the aspect of writing. This approach neglects the impact that orality actually had in the legal setting, and continues to have to the present today. Therefore, I would like to pursue the thesis that the judiciary is one of the few contexts in which orality and literacy have been systematically interconnected. ${ }^{5}$ It was the legal system where these two modes of communication existed in a largely interdependent and co-constitutive form. One could even assert, more precisely, that it is in the courtrooms of contentious jurisdiction that orality has remained a mandatory precondition for literacy. At the same time, this very literacy is retranslated into orality again in order to effect the agency of written artefacts as legal documents. This process raises questions about how manuscripts created by legal courts were produced and used in concrete terms. How was the process of writing those transcripts organised? Who wrote and under what conditions? What is the legal status of these court records? What changes took place, when, for example, shorthand was implemented in court? Beyond these questions about the performativity of writing and the practices involved in the writing process, we ought to consider the role of orality more closely by taking into account the objectives, conditions, and obstacles which orality poses and the respective practices that intertwined the spoken and the written word, namely, the simultaneous acts of speaking, listening, and writing.

In order to address these questions from a historical perspective, and to understand the characteristics of written artefacts as an outcome of the aforementioned practises, I will first look at the formal legal requirements. A larger framework, examining the connection between orality and literacy by comparing the differences between national legal systems, both within Europe and beyond, would be desirable. ${ }^{6}$ However, the topic proves to be considerably complex. Therefore, as a first step I will roughly outline the German conditions in the nineteenth and early twentieth century. Second, I will address orality and the specific modes of speaking and their institutional setting in German courts:

5 Gensler 1821, 12-18.

6 Mittermaier 1845 provides a valuable overview of the importance of oral and written legal evidence and the national peculiarities in certain areas, including some of the German states (Baden, Bavaria, Holstein, Prussia, Saxony, Schleswig, Württemberg), some European countries (Belgium, England, France, Greece, Hungary, Ireland, Italy, Portugal, Scotland, Switzerland), North America, and Brazil. 
How was orality practised? What were the specific conditions and problems? And to what extent is orality accessible in the written record at all? As a third point, and instead of a linear reconstruction of history, I will illustrate the peculiarity or even the interdependence of the written and spoken word at court by referring to the vigorous debate about the introduction of stenography into German courtrooms of contentious jurisdiction. These conflicts in the nineteenth century allow us, on the one hand, to gain insight into earlier practices at court, which served as arguments for modernisation at the time. On the other hand, and this is the fourth point, these conflicts also deal with the legal issues of writing in court, that is, with changes in organisation and argumentation. One of the main questions refers to the status of shorthand records as fully valid and reliable documents, or, more precisely, to their agency as originals that provided legal certainty.

\section{Recording orality at court: The German legal framework}

Research dealing with the production and use of manuscripts in justice, jurisprudence, and legal practice is obviously important because the legal system as a whole is of great social and cultural significance. Moreover, this is a key area in which scholars have assumed that the written word took and even maintained precedence at a very early stage. ${ }^{7}$ Accordingly, they argue that the spoken word lost its significance in view of the predominance of a specific mode of juridical literacy concerning law and written testimony. This argument assumes that a legal system dependent on inquisitorial trials ${ }^{8}$ was fundamentally based on the exclusive use of written evidence. A closer look at the conditions in the German states beginning in the early nineteenth century, however, reveals that

7 Goody 1986, 127-170; Gardey 2019, 54-58; Vismann 2000.

8 In the German context, the term Inquisitionsprozess (inquisitorial trial), and the concept underlying it, date back to Roman law and were based on the following principle: quod non est in actis, non est in mundo ('What is not recorded does not exist'). Here the position of the prosecutor and the judge were identical. The files were produced in a non-public proceeding only by the judge-cum-prosecutor, and the documents then had to be passed on to legal academic scholars outside the court or to a competent tribunal for decision-making (Zopfs 2018). See also Bennecke, Beling 1900, 258; Eser 2014; Kienitz 2005. The Inquisitionsprozess is not to be confused with the historical institution of the Inquisitional trial, which was introduced above all by the church to fight against heresy. 
a major change had taken place. The legal system was now grounded primarily on the principle of orality. Court proceedings from the Kingdom of Württemberg prove that even the inquisitorial trials relied on verbal protocols. The statements of the participants 'so weit es seyn kann, mit den eigenen Worten der Zeugen, und zwar in der ersten Person, zu Protokoll gebracht werden sollten' ('were to be put on record as far as possible in the witnesses' own words, and in the first person'). ${ }^{9}$ Since at least the middle of the nineteenth century, the official obligation of immediacy in oral presentations and thus the 'Gleichzeitigkeit des gegenseitigen Vorbringens' ('simultaneity of adversarial pleadings') ${ }^{10}$ was at the centre of the German legal system. Consequently, the German Strafprozessordnung (Code of Criminal Procedure) established the orality of legal proceedings as a precondition in accordance with the 'Prinzip der Unmittelbarkeit in mündlichen Anhörungen' ('principle of immediacy in oral proceedings'). ${ }^{11}$

When we talk about legal enquiries in proceedings of contentious jurisdiction, then we are primarily concerned with the taking of evidence, the interrogation of the accused, and the examination of witnesses and their testimonies during the main trial. The requirements stated,

\footnotetext{
dass alle Verhandlungen, welche der Entscheidung zur Grundlage dienen sollen, also Angriff, Vertheidigung, Beweisführung und Rechtsbegründung vor den Richtern, welche das Urtheil fällen sollen, selbst und zwar mündlich geführt werden. ${ }^{12}$
}

that all proceedings which are to serve as a basis for the decision, i.e. the prosecution, defence, presentation of evidence, and legal reasoning, will be conducted in person, that is, orally before the judges who are to render a verdict.

All of those communicative but ephemeral acts were mandatory parts of a trial. Only the oral performance could guarantee that the judge in charge of the verdict would hear the unfiltered truth of all participants under the compulsion of his questioning. ${ }^{13}$ Another important aspect was that the testimony took place in the presence of the accused and his or her lawyer. This involved the "Möglichkeit, sich über jede entgegenstehende Aussage zu erklären, sie zu berichtigen und Fragen an die Aussagenden zu stellen' ('the opportunity to explain themselves with regard to any contradictory testimony, to correct it and to ask questions of

\footnotetext{
9 Reyscher 1839, 721.

10 Gerau 1850, 417; Mittermaier 1845.

11 Mittermaier 1856, 305-316; Gerau 1850; Vismann 2011, 112-129.

12 Gerau 1850, 419-420. Unless otherwise stated, all translations in this article are mine.

13 Bennecke, Beling 1900, 258.
} 
those giving evidence'). ${ }^{14}$ Prefabricated texts and written statements had no legal validity whatsoever. Their use was explicitly prohibited. ${ }^{15}$

Nevertheless, due to the limited capacity of the human memory, records of the proceedings had to be written down. They would render all statements comprehensible and replicable word for word. ${ }^{16}$ This requirement meant in turn that the spoken word was at the same time transcribed into regular Kurrentschrift (German cursive script) by a professional scribe, a process which transformed the spoken word into a legally effective court file. In this process, ephemeral speech not only became a document, but it also gained tangible materiality. The oral statements were documented by handwriting, mainly verbatim:

Die Aussagen des zu Vernehmenden sind nicht im erzählenden Style, sondern in der ersten Person, und, soweit es möglich ist, in denselben Ausdrücken, worin sie geschehen, nöthigenfalls mit den eigenen Erläuterungen des Redenden, im Protokolle niederzuschreiben. ${ }^{17}$

The statements of the interrogated are not to be recorded in the narrative style, but in the first person, and, as far as possible, in the same terms in which they are made, if necessary with the speaker's own explanations.

The spoken word should be transcribed 'in möglichster Treue und Vollständigkeit' ('with the greatest possible fidelity and completeness') ${ }^{18}$ to serve as evidence of what the people under interrogation had put on record. Because it ensured a certain degree of control about what was said both for the defence and for the prosecution, the transcript could be used later to appeal the case. Likewise, the legal officers and judges could use the transcript as an argumentative basis in their assessment and adjudication. In order to validate the records, the scribe himself had to read them out at the end of the very same court session to allow for corrections and additions.

To cite an example: the Stadtratsprotokoll in gerichtlichen Sachen (city council records for legal affairs) of Hall in the kingdom of Württemberg for January 25th in 1825 documents a case of blackmail on account of sexual intercourse and a

14 Mittermaier 1856, 308.

15 The Urkundenbeweisverbot (prohibition of documentary evidence) refers to records submitted in the absence of a judge in charge of the verdict (Bennecke, Beling 1900, 341).

16 Lamm 1867, 219.

17 Knapp 1843, 40.

18 Knapp 1843, 150. 
falsely alleged pregnancy..$^{19}$ After the first round of evidence was recorded, the case was submitted to the district court. Looking at the layout of the page, it is obvious that the scribe made some additions in the margins. It is very likely that he inserted these addenda simultaneously or right after officially reading out the statements. There are also some corrections throughout the text, which the scribe must have introduced during the hearing. One assumes that he noticed his mistakes while he was still writing and corrected them immediately.

As a next step, the respective speakers had to sign the record of their testimony. In so doing, they confirmed the accuracy of the record and made their own words legally effective. At the end of the testimony, a fixed formula is inserted that says: 'Auf Verlesen bestätigt die Angabe die Bekl.(agte) mit ihren Handzeichen' ('After the reading, the def.[endant] confirms the statement with her initials'). Obviously, the female defendant, Caroline Dillinger, could not even write her name or initials. Instead, she chose to sign with three crosses, which, because of their clumsiness, may also indicate that she had no experience in using a quill. At the bottom of the page, a signature confirms the presence of a witness. Here it says: 'Auf Verlesen' ('confirmed after the reading'). It seems that this person could write her name, but the awkward letters reveal that she lacked practice.

In this respect, the efficacy of the protocol as a legal document was based exclusively on the combination of orality and the authentication of the speaker's signature, as well the signatures of the judge and the scribe. In the end, the verdict relied on those court proceedings.

\section{Orality in court and its implications for recording}

The oral proceeding was the centrepiece of the trial as such. Even the possibility of speech impediments or foreign-language participants is a topic here. ${ }^{20}$ All parties including the judge had to express themselves in the presence of the court and make their pleadings verbally. Orality referred not only to the presentation of the testimony, but also to reading out the court record: 'Das Protokoll

19 StAH, Stadtratsprotokoll in gerichtlichen Sachen, 19/480, hearing of Caroline Dillinger and Elisabeth Schüle, 25 Jan. 1825.

20 Knapp 1843, 69-70; Civilprozeßordnung 1898, 47-48. 
ist - in der Hauptsache - dazu bestimmt, vorgelesen zu werden' ('The transcript is - in the main - meant to be read out'). ${ }^{21}$

When looking at concrete examples, however, the question arises as to how much orality is actually included in these written records. After all, one must concede that orality is only accessible through the transcription of the spoken word. It therefore is reasonable to distinguish between the agency of the participants as authors and as originators. The speaker is, so to say, the author of his or her story; the speaker, the scribe, and the judge co-acted as originators of the written artefact. Of course one has to admit that the oral presentation was ipso facto subject to the power of the scribe. ${ }^{22}$ Thus, the very idea of immediacy at court seems to be a legal fiction. For one thing, the linguistic ability of the participants to understand and to express themselves might affect the questioning. Likewise, their familiarity with the cultural context, namely, the specific situation of being called to court, might have some impact. In order to assess the conditions of recording, a basic question is how fast and in what mode and temper people spoke. One might imagine differences in speech when they explained their views and argued, when they defended themselves, when they depicted or remembered facts and circumstances, or when they delineated excuses and invented lies. Even more important is that the skills of the scribe and his capacities in speedwriting dominated the situation. It was his task to document the argumentation in detail while grasping the content of the spoken statement. $^{23}$

Keeping this situation in mind, one must acknowledge that the official claim of a word-for-word transcription always includes some kind of translation. ${ }^{24}$ First, a translation into the standard language is in most cases recognisable. The fact that people spoke dialect can be assumed, but is hardly visible here. Secondly, the written artefact itself cannot depict the emotional colouring of the speech, for example, fear or anger. There are some instances, however, in which the scribe made the volume of the voice or the manner of speaking visible via commentary. For example, when he added the information that the accused had spoken 'hastig' ('hastily'), 'sich lange besinnend' ('reflecting at length'), 'bestürzt' ('stunned'), 'in brutalem trotzigen Thon' ('in a harsh, defiant tone'),

21 Flemming 1898, 585.

22 Gensler 1821, 157.

23 Kienitz 2005, 59-70.

24 Göttsch 1991, 445. However, her examples originate from trials in the eighteenth century and therefore still pertain to the inquisitorial trial. The records represent the hearing in detail, but the scribe paraphrased into indirect speech. 
'schnippisch und mit pochendem Herzen' ('caustically and with a pounding heart'), 'bißig' ('cutting'), 'mit sehr stotternder, kaum zu vernehmender Stimme' ('in a stammering, barely audible voice'). ${ }^{25}$ Apparently, the description depended on his interpretation, such as when the scribe differentiated the manner in which an accused person responded to questions, by 'weinen' ('crying'), 'heulen' ('wailing') or 'bitterlich weinen' ('weeping bitterly'). There is also some evidence that female defendants became verbally abusive. They cursed blatantly and insulted each other in such a way that the judge had to call them to order repeatedly for 'unschicklicher und unziemender Reden' ('indecorous and unseemly speech'). ${ }^{26}$

Moreover, the scribe translated the oral statements into a distinctly written form of speech. This is perceptible in the smoothed-out sentence order, as well as in the phrases that are to some extent adjusted to make sense. Usual filler words or repetitions, which are characteristic of unscripted spoken language, are rather rare, but there are examples, such as: 'Ey, ey, da kräuselt es mir. Ich hatte nichts mit ihm' ('Well, well, it gives me the creeps. I had nothing to do with him'). ${ }^{27}$ Likewise, it is noticeable that in contrast to everyday speech, people seem to present their narration in complete sentences.

Evidently, there was a cultural authority of the written language, which fully asserts itself here and transforms to some extent the previous orality. In this respect, literacy seemed to have been an instrument of domination and power. ${ }^{28}$ One must also suppose that the conditions of judicial interrogation played a role, since the terminology used by the judge followed the interests of the judiciary. One must look closely to determine whether people merely repeated the judge's phrasing or whether they used words of their own accord. Sometimes witnesses or defendants even adapted their own language to the expectations of the judge in anticipatory obedience, such as when people had had previous experiences with the juridical authorities, which were documented in their personal criminal record.

The introduction of the principle of orality was much discussed in the 1830s. Jurists and legal scholars considered it innovative because it strengthened the

25 StAL, Kriminalsenat Ellwangen, E 341 I, Bü 37, 'Strafsache gegen Maria Katharina Röthlin (Röthel), Christine Schön und andere aus Schwäbisch Hall wegen gewerbsmäßiger Unzucht', hearing of Magdalena Bäuerle, 7 Aug. 1824.

26 StAL, Kriminalsenat Ellwangen, E 341 I, Bü 36, hearing of Johanna Friederike Walter, 17 May 1824.

27 StAL, Kriminalsenat Ellwangen, E 341 I, Bü 37, hearing of Rosina Maria Treuter, 4 Aug. 1824.

28 Göttsch 1991, 450. 
position and the rights of people who were in court, defendants as well as witnesses. ${ }^{29}$ However, the change also brought with it some problems. For handwriting was the central means of recording these ephemeral situations. The transfer of verbatim speech to a written form as an authoritative process of notarisation was in the hands of a more or less ambitious or experienced scribe.

\section{Longhand script and the legibility and legality of shorthand}

The legal regulations tell us a lot about the requirements and organisation of orality in court. By contrast, guidelines on the subject of writing in court are scarce. ${ }^{30}$ In this respect, only the vigorous debate about the introduction of shorthand in the 1860s opens up the possibility of further investigation. The specific practices involved in creating longhand transcripts only became an issue, and therefore visible in archival records, when they were challenged by the concept of a new and time-saving documentation system. As the experts discussed the specifics of shorthand and its characteristic elements - for example, simplification of common writing and illegibility of a non-alphabetic script - the faults and benefits of both longhand and shorthand came into view. In the following paragraphs, two aspects of this debate will be explicitly addressed: first, the conditions of writing longhand as such and their effects on script; and second, the legal dimension of shorthand records.

Obviously, the previously described form organising court proceedings, that is, orality and the obligation to record the spoken statements immediately and verbatim, would have been an ideal playground for the use of shorthand. ${ }^{31}$ Yet the opposite was the case: whereas in other countries, for example in England, the use of shorthand had long been common practice, even in the field of

29 As one of the main outcomes, Mittermaier mentions that the number of acquittals had decreased significantly (Mittermaier 1856, 306, n. 4).

30 According to Gensler 1821, 164, the scribe should avoid 'gewisse Schriftzüge, die das Lesen erschweren und erst einer Entzifferung bedürfen' ('any style of lettering that makes reading difficult and requires decipherment'). Pörschel 1911, 20-22, gives some details on the type of paper to use and insists on the use of black ink.

31 Menger 1873, 155-167, discusses the necessity of elaborate records for appealing a case. He also stresses the technique of shorthand as an essential tool for improving the quality of the records (p. 166, n. 33). 
law, ${ }^{32}$ the German state authorities refused to apply the system. The earliest evidence of shorthand in German courts dates to the beginning of the twentieth century. ${ }^{33}$ Why were the German state authorities so hesitant, and why did it take so long for shorthand to finally be used in court?

The discussion about the use of shorthand in the German judiciary began in the 1860s and relied on the positive experiences with parliamentary shorthand. ${ }^{34}$ The promoters described a multitude of advantages of the new method, which included saving time, saving manpower, and saving material resources. ${ }^{35}$ The main concern was to offer an alternative to the German cursive script or Kurrentschrift, which they faulted for being 'mühsam dahinschreitend' ('slow and cumbersome') and 'allzu schwerfällig für den mächtig und rasch arbeitenden Geist' ('all too clumsy for the powerful and fast-working mind'). ${ }^{36}$ The proponents of shorthand disapproved of longhand above all because of the large number of hand movements necessary for its many somewhat crooked characters:

Die deutsche Currentschrift nimmt in Folge ihrer Weitschweifigkeit und Vielzügigkeit, insbesondere der häufigen Erhebung und Senkung ihrer Zeichen über und unter die Schreiblinie einen nicht geringen Aufwand an physischer Kraft und Zeit in Anspruch, lenkt daher die Aufmerksamkeit in zu hohem Grade auf die mechanische Thätigkeit des Schreibens $\left[\ldots . . .{ }^{37}\right.$

German cursive script requires - due to the fact that its letters are too lengthy and consist of too many strokes, in particular because of the frequent elevation and descent of its characters above and below the writing line - a considerable amount of physical effort and time; therefore it directs one's attention too much to the mechanical activity of writing [...].

Fast recording at court by using longhand script was very physically demanding. Not only did the scribe need impeccable hearing, but a quick grasp and excellent memory skills were also essential. Simultaneously listening, understanding,

32 Zeibig 1867; Gardey 2019, 40.

33 GLAK, Badisches Justizministerium, 234 Nr. 9191-9192, 'J.U.S. gegen Frh. Karl von Lindenau wegen Erpressungsversuchs, Beleidigung und Begünstigung', stenographic record of the main proceedings for 19 Dec. 1907. I thank Hannah Boedekker for this information.

34 Zeibig 1867; Lamm 1867.

35 Mittermaier 1856 was the first to argue that the employment of publicly appointed and sworn shorthand scribes would improve the quality of the court records (Mittermaier 1856, 311). 36 Zeibig 1867, 25.

37 Lamm 1867, 209. He claimed that cursive letters require 'durchschnittlich je fünf Handbewegungen, einige sogar acht' ('an average of five hand movements each, some even eight'), whereas shorthand only requires two or three (p. 210, n. 6). 
remembering, and reproducing what he heard required a lot of mental attention and retentiveness. These physical and mental aspects are especially interesting: producing records at court in longhand and cursive script thus seemed exhausting not only for the body and the hand holding the quill, but also for the mind. A professional scribe, it was said, would be worn out in nine to ten years due to the demanding requirements at court. That the mental and physical difficulty of the task could become a problem in court sessions is also evident from the many complaints 'über den Zeitverlust bei solcherart langsamen Beamten' ('about the loss of time caused by some slow scribes'):

Man erinnere sich nur der lähmenden Pausen, welche daraus entstehen, daß dem Protocollführer Zeit zum Nachschreiben vergönnt werden muß, [und] der unerquicklichen Debatten, welche sich nicht selten bei dem Vorlesen des Protocolls sich darüber entspinnen, ob der Angeschuldigte oder ein Zeuge das oder jenes ausgesagt habe, und in der Regel nicht anders, als durch nochmalige Befragung oder Vernehmung zum Abschluß gebracht werden können. ${ }^{38}$

One only has to remember the paralysing pauses that arise from the fact that the record keeper has to be allowed time to complete his writing, [and] the unpleasant debates that frequently arise during the reading out of the records as to whether the accused or a witness has stated this or that, and which usually cannot be brought to a conclusion other than through repeated questioning or interrogation.

In view of these complaints, it is easy to understand the basic need for a script at court that was more manageable for body and mind than the inconvenient, slow, and laborious German longhand cursive script. In order to meet the increasingly high demands, the experts of shorthand required: 'Es muss daher jedes Schriftsystem, welches auf Vollkommenheit Anspruch macht [...] die Mittel bieten, so schnell zu schreiben, als man zu sprechen im Stande ist'. ('Therefore, any writing system that claims to be perfect [...] must provide the means to write as fast as one is able to speak'). ${ }^{39}$ In their view, the regular German cursive script was insufficient: 'Die Stenographie allein ist im Stande, ein vollständiges und treues Bild der mündlichen Verhandlung wiederzugeben und doch mit der Verhandlung selbst gleichen Schritt zu halten [...]'. ('Shorthand alone is capable of reproducing a complete and faithful account of the oral proceedings and yet keeping equal pace with the proceedings themselves [...]')..$^{40}$

38 Lamm 1867, 219.

39 Tietz 1872, 26.

40 Lamm 1867, 219. 
In addition to these problems caused by the complexity of the script and the techniques of handwriting itself, there were also some technical obstacles. One of them was the writing support, namely the paper, which, depending on the quality, might be so rough that it dulled the quill in no time:

Die Oberfläche der unzähligen Papiersorten besteht sehr oft aus Substanzen, welche die Schärfe der Feder angreifen und abstumpfen. Wird doch schon ein Messer womit wir Papier schneiden stumpf, weil es Theile enthält, welche der Schärfe des Messers widerstehen, vielmehr noch greifen diese Theile die Schärfe einer Feder an. ${ }^{41}$

The surface of the countless types of paper very often consists of substances that damage and dull the sharpness of the quill. Even a knife with which we cut paper becomes blunt, because the paper contains particles that resist the sharpness of the knife, but even more so do these particles damage the sharpness of a quill.

Rough paper also disturbed writing smoothly. The uneven surface caused friction, hampered and interrupted the movement, as if it tugged at the quill or the nib of a steel pen. The script would turn out untidy, stained, and splattered. If the ink was too thin, it seeped into the paper too quickly, and blotted, ruining the appearance of the document, taking away from its official air and authority. If the ink was too thick, writing did not progress smoothly or fast enough. In both cases, either the time spent waiting for the ink to dry or the use of grit increased. Moreover, the aggressive substances of the ink damaged the quill, which, if it was not greasy enough, quickly became ineffective. The problem of the quill becoming too soft for writing could be solved

wenn man etwa zehn bis zwanzig Kiele zugleich in Gebrauch nimmt, die abgeschriebene Feder hinlegt, eine neue ergreift und die gebrauchten Federn erst dann wieder zuspitzt, wenn sie hart geworden sind..$^{42}$

by using about ten to twenty quills at the same time, putting down the worn-out quill, reaching for a new one, and sharpening the used quills only when they had hardened again.

Scholars of the art of writing, such as the Prussian instructor Carl Friedrich Stiehr, insisted that writing was a highly complex process in which all components should be in good shape and well coordinated in order to ensure smooth writing and a clear and legible script:

41 Stiehr 1832, 28.

42 Wieck 1853, 318. 
Die Geschicklichkeit der Hand, die Güte der Posen, die Richtigkeit des Schnitts und die Güte des Papiers und der Dinte schließen sich so aneinander an, greifen so ineinander, daß gleichsam das eine ohne das andere nicht möglich ist. ${ }^{43}$

Manual dexterity, the quality of the poses [i.e. the goosequill], the precision of the cut, and the quality of the paper and the ink are so interconnected, so intertwined, that it is impossible to have one without the other.

While a 'gute Feder' ('a good quill') ${ }^{44}$ was relatively easy to obtain, the manuals addressed the difficulties for the scribe in achieving the habit of a 'gute und flüchtige Hand' ('a fine and quick handwriting'). In the eighteenth century, calligraphers such as Johann Stäps from Leipzig in his 'Selbstlehrende Canzleymäßige Schreibe-Kunst' ('Self-Instruction in the Art of Clerical Writing') ${ }^{45}$ gave elaborate instructions on how to sit at the table, how to position both arms and feet, and how to cut and hold the quill. He taught both cursive and chancery script, pointing out above all the differences not only in hand posture, but also in cutting the quill and in pen style, as these pertained to the different scripts. ${ }^{46}$

It took time to develop expertise in writing a fast and legible longhand script. ${ }^{47}$ Nevertheless, learning shorthand was just as challenging to say the least. An official report from 1914 - at that time shorthand had already been introduced in Hamburg's courts for some years - noted with regret, that the older clerks in particular had not been able to adapt to the new writing system, because they apparently lacked the requisite physical agility and motor skills of the hand. Not even their declared 'diligence, perseverance, and persistence ${ }^{448}$ sufficed; that is why the use of shorthand had to be left to younger staff members. Shorthand placed special demands on posture and especially on the wrist: the greater angle of inclination made it necessary to write with a pencil. Furthermore, the surface of the paper had to be very smooth and plain without

43 Stiehr 1832, 9.

44 'Eine gute Feder sei eine, die, ohne daß man viel drückt, leichtweg schreibt' ('a good quill is one that writes easily without the need for much pressure'), according to the German writer Georg Christoph Lichtenberg, quoted by Stingelin 2012, 293.

45 Stäps 1748.

46 Stäps 1748, 5.

47 According to Frank 1919, 84, one of the main criteria for employing a scribe would be a 'schöne Handschrift' ('beautiful handwriting').

48 StAHH, Hanseatisches Oberlandesgericht. Stenographie im Gerichtsdienst, 213-1_1961, 'Bericht betr. die Einführung der Kurzschrift bei den hamburgischen Gerichten' ('Report on the Introduction of Shorthand in the Courts of Hamburg'), 8 June 1914, p. 3-4. 
lines to give the scribe room to move..$^{49}$ On the other hand, it was seen as a great advantage that a scribe well trained in shorthand from the beginning of his career could maintain his mental and physical strength and thus remain in service as much as seven to nine years longer than a longhand scribe. ${ }^{50}$

\section{Legal arguments against the implementation of shorthand}

Even though there were many practical arguments in favour of using shorthand in the courtroom, the specific nature of this writing system served as a major counterargument. In putting forth legal reasons, opponents referenced the secrecy associated with shorthand. They argued that the seemingly encrypted script was illegible to outsiders or even to practitioners of a different shorthand system. ${ }^{51}$ The inaccessible nature of shorthand would violate the legal norm that every scribe had to be able to read out the written record ad hoc and accurately in the presence of all participants. This requirement pertained not only to the individual scribe but also to his colleagues, when, for example, there was a change in staff during a court session.

There were some other reasons why the legal authorities so persistently rejected shorthand in German courts. A primary reason was the absence of a common shorthand writing system. Neither were there any regulations for implementing shorthand as a mandatory script in legal administration. The respective lobbying associations, favouring either the system of Gabelsberger or Stolze-Schrey, were still in fierce competition with each other. ${ }^{52}$ Besides, it was not even mandatory for scribes to take lessons in shorthand. The general use and acceptance of shorthand in legal matters made no sense as long as it was the scribe's private decision as to what system to use or to stick to longhand. In view of these inconsistencies, legal experts argued that shorthand records would not meet basic legal requirements. They refused to accept shorthand as an official mode of documentation at court,

weil die nur dem Eingeweihten verständliche stenografische Niederschrift selbst ein Protokoll nicht darstellt und die Uebersetzung in Currentschrift eben nicht das aufge-

49 StAHH, 213-1_1961, 'Bericht betr. die Einführung', p. 4.

50 StAHH, 213-1_1961, 'Bericht betr. die Einführung', p. 7.

51 Lamm 1867, 205.

52 Lamm 1867, 206; Funke 1913. 
nommene Protokoll ist, deshalb aber mittelst der Stenografie ein Protokoll im technischen Sinne des Wortes überhaupt nicht gewonnen werden kann. ${ }^{53}$

since the stenographic transcript, which can be understood only by the initiated, does not constitute a protocol, and the translation into cursive script is likewise not the recorded protocol, therefore, a court record in the technical sense of the word will never be obtained by means of stenography.

Despite all these legal objections, the German shorthand lobby still insisted on the indispensable qualities of stenography as 'mächtiges politisches Bildungsmittel' ('a powerful political tool for education'),,$^{54}$ that, because of its speed and accuracy, was most useful especially in court. It was well into the first decade of the twentieth century before shorthand gained acceptance as part of the bureaucratic reforms in Germany, but this acceptance was also due to the increasing workload in the administrative legal system. ${ }^{55}$

With the introduction of shorthand, court routines changed to a certain extent. The schedule of the court session itself remained the same in terms of procedure. The scribe noted the questions and answers down accurately, but now did so in shorthand. Then he read out the recorded testimony from this very record, and subsequently all parties involved certified their submissions. An example from the Hamburg Amtsgericht (local court) shows that people were putting down their signature right on the shorthand transcript itself. ${ }^{56}$ Hence, they perceived and used the illegible transcript the same way that an earlier longhand manuscript would have been used. Now the very act of signing turned the shorthand records into a legally effective document.

With regard to some archival examples from Hamburg, which were produced during the 1920s, it should be noted that the typewriter and with it the carbon copy was already accepted and widespread as an important tool for office work..$^{57}$ In the years before this technical revolution took place, however, the procedure for transcribing shorthand records was still as follows. After the court session was finished, the shorthand document was sent to the chancery.

53 Zeibig 1867, 12.

54 Zeibig 1867, 31.

55 Büroreformen 1927; Dumke 1993, 163-167.

56 StAHH, Landgericht Hamburg, 213-11 L 231/1921, 'Akten in der Strafsache M. F. G. wegen Abtreibung', hearing of M. F. G., 13 Oct. 1919.

57 Vismann 2000, 267-276. In Hamburg, the first references to typewritten transcripts date to 1910. StAHH, Hanseatisches Oberlandesgericht, Stenographie im Gerichtsdienst, here: 'Anregungen und Mitteilungen, 213-1_1961, Beantwortung des Schreibens vom 11.3.1910 betreffend Verwendung der Stenographie im Dienste der Gerichte', 14 March 1910, p. 2. 
Here lower-paid clerks transcribed this stenographic record, producing a fair copy in longhand. ${ }^{58} \mathrm{Next}$, they produced several identical replicas for all individual court executives involved. All of these manuscripts, of course, had to be proofread and then signed by the copyist and the judge, not as originals, but as authentic longhand copies, serving the same purpose..$^{59}$

The primary benefit of this bureaucratic modernisation process was that the length of the court sessions noticeably decreased, by a third and up to a half of the time. Thus, the productivity of the judges and the courts increased accordingly. ${ }^{60}$ The time saved on-site during the oral proceedings, however, was often lost due to delay in the back office, where the scribes had to spend more time on clerical duties. ${ }^{61}$ As the complaints about sick leave and frequent changes of clerks show, the court's efficiency also depended on the productivity of the scribes. ${ }^{62}$ This situation meant that the administration was effectively subject to certain rationalisation strategies, including Taylorism ${ }^{63}$ and cost-cutting measures. Such measures resulted in an increasing number of administrative jobs and thus expanded the hierarchy of clerical services at court. This situation created new possibilities for building a career in administration. ${ }^{64}$ Most of the scribes started as ordinary assistants and tried hard to improve their skills as scribes on the job, as well as to acquire legal knowledge, in order to rise to a position as Sekretär or Obersekretär (secretary or senior secretary) or even higher positions. ${ }^{65}$

58 StAHH, Hanseatisches Oberlandesgericht, Stenographie im Gerichtsdienst, here: Anregungen und Mitteilungen, 213-1_1961, 'Beantwortung des Schreibens vom 1.4.1908 betreffend Verwendung der Stenographie’, 6 April 1908, p. 1.

59 StAHH, Hanseatisches Oberlandesgericht. Stenographie im Gerichtsdienst, 213-1_1961, 'Bericht betr. die Einführung der Kurzschrift bei den hamburgischen Gerichten' ('Report on the Introduction of Shorthand in the Courts of Hamburg'), 8 June 1914, p. 5.

60 Lamm reported on test runs in which they measured the time necessary to record a testimony in shorthand, read it out, and translate the shorthand record back into longhand (Lamm 1867, 222-223); StAHH Hanseatisches Oberlandesgericht, Stenographie im Gerichtsdienst, here: Anregungen und Mitteilungen, 213-1_1961, 'Beantwortung des Schreibens vom 1.4.1908 betreffend Verwendung der Stenographie’, 6 April 1908, p. 3.

61 StAHH, 213-1_1961, 'Beantwortung des Schreibens vom 1.4.1908', 6 April 1908, p. 3.

62 StAHH, Hanseatisches Oberlandesgericht, Nichtrichterliche Beamte, here: Gerichtsschreiber, 213-1_1842, 'Präsident Brandis an den Senatskommissar in Angelegenheiten des OLG', 11 July 1912.

63 Winter 1920, 187-190, 222-223.

64 Thiesing 1927, 18-19.

65 StAHH, Hanseatisches Oberlandesgericht, Nichtrichterliche Beamte, here: Gerichtsschreiber, 213-1_1842, 'Bewerberlisten', p. 2; see also Geschäftsordnung 1905, 5. 


\section{The agency of shorthand records}

Many years, it seemed rather unlikely that artefacts written in shorthand could ever serve as legal documents. Obviously, the German authorities then changed their attitude to this problem at the beginning of the twentieth century. For some courts of justice in the states of Baden and Hamburg, there is evidence that shorthand transcripts survived as part of the court record, which proves that these transcripts really did act as official legal documents. ${ }^{66} \mathrm{I}$ shall return to this point in a moment. In addition, the Prussian Minister of Justice regularly requested reports from the German states on the implementation of shorthand as a work- and time-saving tool at the individual courts. ${ }^{67}$

As the files in the State Archives of Hamburg demonstrate, the court administration authorities were very anxious to systematically improve the shorthand training of scribes at court, even before the introduction of German Unified Shorthand in 1924. On the one hand, these authorities employed only scribes with a certified knowledge of shorthand. Furthermore, starting in the 1910s, scribes in Hamburg, who were about 150 in number, received regular training in shorthand, with classes for newcomers even during office hours. ${ }^{68}$ Skill in reading aloud one's own handwriting (and doing it quickly and from a standing position) was particularly important. Therefore, shorthand teachers dictated practice oral testimony twice a week; the scribes-in-training were supposed to constantly optimise their skill in listening and writing quickly.

There remains the question of how acceptance of shorthand records and their agency as part of court proceedings was legally certified. How did the judicial authorities solve the problem of authenticating the illegible script? To answer this question I again refer to the Hamburg archival material. When reviewing court files of contentious jurisdiction from the 1920s, I came across multipage stenographic records. ${ }^{69}$ These records were tied together and bound into

66 GLAK, Badisches Justizministerium, 234 Nr. 9191-9197, 'J.U.S. gegen Frh. Karl von Lindenau wegen Erpressungsversuchs, Beleidigung und Begünstigung', stenographic record of the main proceedings for 19 Dec. 1907; stenographic records and their translation (1907-1908); GLAK, Badisches Justizministerium, 234 Nr. 9107, 'J.U.S des R.A. Karl Hau aus Großlittgen wegen Mords', stenographic records (1907-1926).

67 StAHH, Hanseatisches Oberlandesgericht, Stenographie im Gerichtsdienst, here: Anregungen und Mitteilungen, 213-1_1961.

68 StAHH, Hanseatisches Oberlandesgericht, Stenographie im Gerichtsdienst, 213-1_1961, 'Bericht betr. die Einführung der Kurzschrift bei den hamburgischen Gerichten' ('Report on the Introduction of Shorthand in the Courts of Hamburg'), 8 June 1914, pp. 3-9.

69 StAHH, Landgericht Hamburg, 213-11. 
the respective files, always accompanied by other documents written in longhand and typewritten artefacts. Fortunately, I did not have to learn shorthand to work with this material. For I soon recognised that in each file there were two versions of the very same record both referring to the same court hearing, and always arranged in the same order. First came the typewritten version, which of course was easy to read, even if the scribe used many abbreviations that were at first unknown to me. Then followed the shorthand version, whose script was spread out on the page in an unordered manner, illegible to me, except for some individual words written in both scripts, shorthand and longhand. Therefore, it was not at all a question of deciphering the shorthand script to get at the meaning of the records. Much more relevant was the materiality and significance of the written artefact itself as part of common legal practices.

In most cases, legal procedures result in written artefacts of some sort, whose originality had to be certified officially, be it through signatures, seals, stamps or other signs of authentication. ${ }^{70}$ The same goes for the stenographic court records. There are two points to discuss here. First is the question of whether those shorthand records could also function as self-contained originals in the legal sense. After all, these records emerged live in the courtroom and documented the very words that had just been spoken in public. Accordingly, the sworn stenographer read out in court his own shorthand record in order to confirm the correctness of its content. As a next step, the witnesses or the accused signed this very sheet of paper. By signing it, they confirmed the document's status as an original and the efficacy of the shorthand record as a legal document, even if only the scribe could read the script.

Now, however, there is a second question, regarding the legal status of the typescript version, which other clerks later produced in the chancery on the basis of the shorthand record. ${ }^{71}$ If the legal efficacy of the document depended primarily on the connection between reading out the recorded statements and the signature of the person giving the testimony, how could a typewritten copy have any legal agency? Would this typewritten document not be more or less just a fair copy without any legal effect, since there were no signatures on it, but only some abbreviations as a reference to the act of reading it out and the fact that somebody had already signed the other document?

70 Strippelmann 1860, 40-69; Pörschel 1911, 21-22.

71 StAHH, Hanseatisches Oberlandesgericht, Stenographie im Gerichtsdienst, 213-1_1961, 'Bericht betr. die Einführung der Kurzschrift bei den hamburgischen Gerichten' ('Report on the Introduction of Shorthand in the Courts of Hamburg'), 8 June 1914, p. 5. 
Surprisingly, regulations such as the German Gerichtsverfassungsgesetz (Code for the Constitution of a Court) do not provide any information on this legal question. Therefore, one can only attempt to answer it on the basis of the available material. If one analyses the details, the conclusion is obvious that there are disparities: there still is a difference in agency between these two versions of the court proceedings. In the end, however, neither version, in and of itself, would have had any legal effect on the course of a trial. Yet I want to put forward the thesis that both documents functioned as originals, though the agency of each depended on the fact that the two were kept together. In this respect, we are not dealing with two entirely distinct originals, but rather with one original that consists of two parts, each confirming the originality of the other. There were two individual yet inseparable written artefacts, neither of which could perform legal agency on its own; the one in shorthand bore the signatures of all the participants and was therefore legally compliant, but it was illegible to outsiders. The other one was a transcription into typewritten script; it ensured by typewriting the legibility of the spoken word. This typewritten version, however, was not legally compliant, since it did not contain the signatures. In this respect, the agency of either document depended on their interconnected relationship, which the authorities preserved by keeping the documents together, both spatially and materially. In some cases, the shorthand transcript was placed in an envelope, sealed and stored, but most of the time it was pinned directly to the typed copy in the file. ${ }^{72}$

In the absence of legal requirements, the judicial authorities solved the problem in a pragmatic way, pointing out the benefit that if there was any uncertainty about the outcome of a hearing, one could immediately evaluate and revise what the scribe had noted in the legal proceedings. ${ }^{73}$ In this way, the stenographic records reaffirmed the crucial importance of orality in court, which was only preserved in handwritten artefacts.

\section{Abbreviations}

$\begin{array}{ll}\text { GLAK } & \text { Landesarchiv Baden-Württemberg, Generallandesarchiv Karlsruhe } \\ \text { StAH } & \text { Stadtarchiv Schwäbisch Hall } \\ \text { StAHH } & \text { Staatsarchiv Hamburg } \\ \text { StAL } & \text { Landesarchiv Baden-Württemberg, Staatsarchiv Ludwigsburg }\end{array}$

72 StAHH, 213-1_1961, 'Bericht betr. die Einführung', p. 6.

73 StAHH, 213-1_1961, 'Bericht betr. die Einführung', p. 6. 


\section{References}

Benne, Christian (2015), Die Erfindung des Manuskripts. Zur Theorie und Geschichte literarischer Gegenständlichkeit, Frankfurt am Main: Suhrkamp.

Bennecke, Hans and Ernst Beling (1900), Lehrbuch des Deutschen Reichs-Strafprozessrechts, Breslau: Franck \& Weigert.

Brauer, Eduard (1852), Das mündliche Verfahren vor dem Unterrichter in bürgerlichen Streitsachen nach der neuen badischen Gesetzgebung von 1851, Karlsruhe: Braun.

Brauer, Eduard (1864), Das Verfahren vor dem Amtsrichter in bürgerlichen Streitsachen nach der neuen badischen Gesetzgebung, Karlsruhe: Braun [2nd revised edn of Brauer 1852].

Büroreformen in einzelnen Verwaltungen (Schriftenreihe Deutsches Institut für wirtschaftliche Arbeit in der öffentlichen Verwaltung, 2), Berlin: Carl Heymann, 1927.

Civilprozeßordnung für das Deutsche Reich nebst dem Gerichtsverfassungsgesetze und den Einführungsgesetzen zu den beiden Gesetzen, Munich: Beck, 1898.

Dernburg, Heinrich (1849), Abhandlungen aus dem Gebiete des gemeinen und französischen Civil- und Proceßrechts in vergleichender Darstellung, Frankfurt am Main: Litterarische Anstalt.

Dumke, Dietmar (1993), Vom Gerichtsschreiber zum Rechtspfleger (Prozeßrechtliche Abhandlungen, 90), Cologne: Carl Heymann.

Eser, Albin (2014), 'Adversatorische und inquisitorische Verfahrensmodelle. Ein kritischer Vergleich mit Strukturalternativen', in Friedrich-Christian Schroeder and Manuchehr Kudtratov (eds), Die strafprozessuale Hauptverhandlung zwischen inquisitorischem und adversatorischem Modell. Eine rechtsvergleichende Analyse am Beispiel des deutschen und des zentralasiatischen Strafprozessrechts (Studien des Instituts für Ostrecht München, 75), Frankfurt am Main: Lang, 11-29.

Flemming, [Hans von] (1898), 'Die Sitzungsprotokolle in den streitigen bürgerlichen Rechtssachen', Sächsisches Archiv für bürgerliches Recht und Prozeß, 8: 577-586.

Frank, Friedrich (1919), Geschichte der mittleren Justiz- $u$. Verwaltungs beamten Badens. Ein Beitrag zur Geschichte der Bureaukratie, Freiburg: Muth.

Funke, Edgar (1913), 'Die Stenographie im Dienste der Verwaltungsbehörden und der Gerichte. Eine Forderung zur Verwaltungsreform', Staatsarchiv Hamburg, 213-1_1961.

Gardey, Delphine (2019), Schreiben, Rechnen, Ablegen. Wie eine Revolution des Bürolebens unsere Gesellschaft verändert hat, [Göttingen]: Konstanz University Press / Wallstein [transl. from French by Stefan Lorenzer].

Gensler, Johann Caspar (1821), Anleitung zur gerichtlichen Praxis in bürgerlichen Rechtsstreitigkeiten, verbunden mit theoretischen Darstellungen und Bemerkungen, Heidelberg: Joseph Engelmann.

Gerau, [Ludwig Friedrich Gottlieb] (1850), 'Ueber Ausführung des Princips der Mündlichkeit im bürgerlichen Prozesse', Archiv für die civilistische Praxis, 33: 416-435.

Geschäftsordnung für die Gerichtsschreibereien des Landgerichts Hamburg, vom 23. Juni 1905, Hamburg: Persiehl, 1905.

Goody, Jack (1986), The Logic of Writing and the Organization of Society (Studies in Literacy, Family, Culture, and the State), Cambridge: Cambridge University Press.

Göttsch, Silke (1991), 'Zur Konstruktion schichtenspezifischer Wirklichkeit. Strategien und Taktiken ländlicher Unterschichten vor Gericht', in Brigitte Bönisch-Brednich und Rolf Wilhelm Brednich (eds), Erinnern und Vergessen (Schriftenreihe der Volkskundlichen 
Kommission für Niedersachsen, 6; Beiträge zur Volkskunde in Niedersachsen, 5), Göttingen: Schmerse, 443-452.

Kienitz, Sabine (1995), Sexualität, Macht und Moral. Prostitution und Geschlechterbeziehungen Anfang des 19. Jahrhunderts in Württemberg. Ein Beitrag zur Mentalitätsgeschichte (Zeithorizonte, 2), Berlin: Akademie.

Knapp, Hermann (1843), Die Strafprozeß-Ordnung für das Königreich Württemberg mit erläuternden Anmerkungen, Stuttgart: Belser.

Lamm, [Karl Moritz] (1867), 'Die Stenographie in ihren Beziehungen zur Rechtspflege', Zeitschrift für Rechtspflege und Verwaltung, NF 28/3: 205-223.

Menger, Anton (1873), Die Zulässigkeit neuen thatsächlichen Vorbringens in den höheren Instanzen. Eine civilprocessualische Abhandlung, Wien: Hölder.

Mittermaier, Carl Joseph Anton (1845), Die Mündlichkeit, das Anklageprinzip, die Oeffentlichkeit und das Geschwornengericht in ihrer Durchführung in den verschiedenen Gesetzgebungen. Dargestellt und nach den Forderungen des Rechts und der Zweckmäßigkeit mit Rücksicht auf die Erfahrungen der verschiedenen Länder, Stuttgart: Cotta.

Mittermaier, Carl Joseph Anton (1856), Die Gesetzgebung und Rechtsübung über Strafverfahren nach ihrer neuesten Fortbildung dargestellt und geprüft, Erlangen: Enke.

Ong, Walter J. (1985), Orality and Literacy: The Technologizing of the Word, 2nd edn, London: Methuen [1st edn: 1982].

Pörschel, Oskar (1911), Der Gerichtsschreiber bei den sächsischen Amtsgerichten. Ein Handbuch für den Gerichtsschreiber, ein Lehrbuch zur Vorbereitung für den Gerichtsschreiberdienst, ein Wegweiser für Jeden, der des Gerichtsschreibers bedarf, 4th revised edn, Leipzig: Roßberg \& Berger [1st edn: 1894].

Reyscher, August Ludwig (1839), Vollständige, historisch und kritisch bearbeitete Sammlung der württembergischen Gesetze, vol. 7/1, Tübingen: Fues.

Stäps, Johann (1748), Selbstlehrende Canzleymäßige Schreibe-Kunst, Leipzig: Brühl.

Stiehr, Carl Friedrich (1832), Belehrung über die erforderlichen Materialien zur Ausübung der Schreibekunst, als: Federposen, Federmesser, Federschnitt und Federverbesserung, Papier, Dinte und Radirmittel, 2nd edn, Berlin: George Gropius.

Stingelin, Martin (2015), “'UNSER SCHREIBZEUG ARBEITET MIT AN UNSEREN GEDANKEN”, in Sandro Zanetti (ed.), Schreiben als Kulturtechnik. Grundlagentexte, 2nd edn, Frankfurt am Main: Suhrkamp, 283-304 [1st edn: 2012].

Strippelmann, Friedrich Georg Lebrecht (1860), Der Beweis durch Schrift-Urkunden, mit Belegen aus der Praxis der obersten Gerichte, Cassel: Fischer.

Thiesing, [Adolf] (1927), 'Reformen in der Justizverwaltung', in Büroreformen 1927, 14-22. Vismann, Cornelia (2000), Akten. Medientechnik und Recht, Frankfurt am Main: Fischer. Vismann, Cornelia (2011), Medien der Rechtsprechung, Frankfurt am Main: Fischer. Wieck, Friedrich Georg (1853), 'Kiel und Stahl', Die Gartenlaube, 29: 317-319.

Winter, Gustav (1920), Der Taylorismus. Handbuch der wissenschaftlichen Betriebs- und Arbeitsweise für die Arbeitenden aller Klassen, Stände und Berufe, Leipzig: Hirzel.

Zeibig, Julius Woldemar (1867), Die Rechtspflege und die Stenografie. Ein Beitrag zur Lösung der Frage: Welchen Nutzen kann die Rechtspflege aus der Verwendung der Stenografie ziehen?, Dresden: Gustav Dietze.

Zopfs, Jan (2018), 'Zur Entwicklung des Strafverfahrensrechts in Deutschland', 〈https://zopfs.jura.uni-mainz.de/files/2018/10/strafe.pdf〉 (accessed on 17 March 2021). 
